\title{
Investigating Procedures for Intuitive GUI design of Indian E- Commerce shopping sites
}

\author{
Megharani Patil, Madhuri Rao \\ (Research Scholar, Information Technology, Mumbai University, India) \\ (Research Guide, Information Technology, Mumbai University, India)
}

\begin{abstract}
This work is all about finding procedures to design intuitive e-commerce shopping websites in India by mapping existing GUI with end user's mental model and behavioral pattern to improve website structure, navigation and interaction. We considered 7 factors, viz. simplicity, readability, learnability, navigability, interactivity, supportability and acceptability for the same. The first three are related to web structure, navigability is related to website navigation and the last three are related to website interaction. Considering these factors, a questionnaire of 27 questions and 10 tasks are designed. Here we have captured the data by conducting a survey of 318 participants. Participants' Demographic data is analyzed and they are categorized into three groups, viz. Beginners, intermediates and experts. We found 66 beginners, 179 intermediates and 73 experts. Mental model for all these groups are formed by referring results of survey in which various statistical measures are applied on Likert score of survey. Task based user testing is done while 10 tasks were being performed by 9 participants and behavioral patterns were recorded. These mental models and behavioral patterns are mapped with GUI of existing e-commerce shopping websites to get findings which helped further to form procedures or design guidelines. These procedures can be used to design intuitive GUI for Indian ecommerce websites.
\end{abstract}

Keywords: Intuitive GUI design, Mental model, Procedures, Website structure, Website navigation, Website interaction

\section{Introduction}

In twenty-first century, as people are busy with their work and commitments, they have only a little spare time. As well as there is wide usage of internet by people to meet their requirements. This has given popularity to online shopping websites in India. To increase conversion rate of shopping websites, they need to have easy-to-use intuitive graphical user interfaces so that all heterogeneous user groups can use it easily. While designing an e-commerce website one must understand it's users, i.e. identify an age group or culture of user [17] as well as one should take care of aesthetics of website, it's layout with readable and appealing visual aspects along with proper colors and Typography [32].User experience and ease of access to accommodate as many users as possible regardless of user skill. User experience, i.e. how well a user understands, how they can interact on a site is related to layout, clear instructions and labelling on a website, i.e. how the interactive design of the site is made [8]. Human Computer Interaction ensures system functionality and usability by providing effective user interaction support, and enhancing a pleasant user experience. It focuses on repeated elicit feedback from users about their experiences with prototyped designs, refining the design based on the suggested changes, repeat this iterative design procedure until the sensible, user-friendly interface is created [14].Design of intuitive graphical user interfaces is possible with a help of solid design guidelines or procedures. Design guidelines are available today such as gestalt principles that support designers in achieving intuitively usable user interfaces. But these guidelines have disadvantages like being only suitable for specific user groups and offering only general advice for the design of user interfaces [18].There are seven principles of user interface design considered during designing the case for HCI Design pattern. These design principles are tolerance, simplicity, visibility, affordance, consistency, structure and feedback [34]. Thirteen principles of human perception and information processing can be utilized to create an effective display design which achieves a reduction in errors, a reduction in required training time, an increase in efficiency, and an increase in user satisfaction [6].There are 10 principles for interaction design which are called as "heuristics" because they are broad rules of thumb and not specific usability guidelines [22]. Donald Norman introduced several basic user interface design principles and concepts that are considered for understanding why some designs are more usable and learnable than others [21]. Research defined a set of usability guidelines such as usability elicitation guidelines, usability elicitation clusters, usability use case Meta model, system responsibilities, and high-level design component responsibilities for software development to help software engineers incorporate particular usability features into their application [35]. There are certain universal "Golden Rules" for user interface design. The golden rules are divided into three groups: Place Users in Control, Reduce Users' Memory Load, Make the Interface consistent [20]. 
To find design guidelines, behavioral science and cognitive theory helps a lot. Behavioral science is the investigation of human behavior by naturalistic observation, and scientific experimentation using rigorous formulations. Cognitive theory is the study of mental processes such as attention, memory, perception, and thinking. This investigation is useful while designing user interface and possible through survey based user testing and task based user testing. The study of finding relationships between content, presentation and usability of websites and how these relate to the overall satisfaction of the user and their willingness to purchase goods and services was carried out through user testing through survey [4]. Aging population may have effects on the usability of ecommerce web sites because as people age, they begin to experience problems with their vision, their hearing, cognitive functions, and their mobility. The findings for the same are carried out though task oriented user testing and survey oriented user testing [31]. When the user interacts with the website to perform a task, he/she is involved in a cognitive activity, sustaining a cognitive cost to search, interpret and process information, and experiencing a sense of satisfaction. The degree of ambiguity and uncertainty he/she perceives and the needed search time determines the effort and the cognitive cost he/she has to sustain to perform his/her task. In total, 9 variables are measured; classified in a set of 3 website dimensions user experience, site navigability and structure. As well as subjective judgment questionnaires are set [33]. Ecommerce sites are one of the fastest growing sites where consumers or users shop things without any burden of being physically present at the shop and receive products at home. We are proposing novel design approaches which will produce the interaction styles and guidelines to help the users to access information and do shopping efficiently [2]. To identify and analyze the extent to which the E-commerce shopping website is fulfilling all the user's requirements and needs this study was done using three research methods; the questionnaire, direct user observation and interviews to investigate the usability and interactivity of the websites design[1].Three usability methods user testing, heuristic evaluation and web analytics were applied to three e-commerce companies and identifying specific usability problems on the e-commerce websites[11]. There are different groups of users with less computer literacy. The first group is elderly users, as users with lack of computer background. The second group is children, as novice users and the third group is users with mental or physical disorders and user interface design principles are investigated such as (a) reducing the number of features available at any given time, (b)avoiding the use of computer terms, (c) putting customization ability for font, color, size and (d) using appropriate graphical objects such as avatar or icon using these principles usability problems are reduced and increased satisfaction of users with less computer literacy[7]. Shneiderman's eight golden rules provide a convenient summary of the key principles of interface design. They are intended to be used during design but can also be applied to the evaluation of systems [29]. In a literature researcher conducted field studies to better understand the impact of the design of the Web site on the consumer buying process [15]. Proposed and tested a theoretical model of the impact of web site design features on trust generation and the final purchase decision [24]. In another literature five variables have been influenced the perceived usefulness and perceived ease of use of a Web site: Product Offering, Information Richness, Storefront Usability, Perceived Service Quality, and Perceived Trust by conducting survey[6]. User testing (usability testing, inspection and inquiry) and open source automated tool like Camtasia are applied to identifying user interface design problems related to four areas: navigation, design, the purchasing process, and customer service[25].The interface design problems of ecommerce online shopping websites from user's preferences and determined the relative importance of factors such as navigability, content, design, ease of use, and structure through user survey[26].The websites were evaluated through task based user testing where the participants' performances for user testing were evaluated in terms of task completion time, success rate, and number of page views As well as post-test questionnaire was administered. Statistical analysis results indicated a significant website-design effect on task completion times [10].Evaluating GUI of e-commerce website by different methods which are stated above one can investigate design guidelines for GUI design but they are not addressing all aspects at a same time. In this work we have addressed heterogeneous users and their level of computer literacy as well all website dimensions.

\section{Methodology}

Three website dimensions are identified to investigate design guidelines or procedures, viz. website structure, website navigation, and website interaction. Method to find procedures for making GUI of ecommerce shopping website intuitive is divided into four steps.

- Documenting the mental model of the end user through survey based user testing.

- Documenting behavioral pattern of end users through task based user testing.

- Mapping GUI of existing e-commerce shopping site with mental model and behavioral pattern of end users.

- Finding procedures to make graphical user interface intuitive.

Documenting the mental model we have conducted online survey through Google docs, where participants of different age group with different level of education and computer literacy were asked to fill the survey. User's demographic characteristics and various website dimensions are considered to conduct the 
survey. Also participants are asked to perform 10 subtasks of online shopping to document behavioral patterns of end users.

\subsection{User's demographic characteristics}

Following are the user's demographic characteristics considered for survey based user testing.

- Age

- Education

- Frequency of using computer and internet

- Frequency of using shopping website

- Name of shopping website which you are using frequently

\subsection{Formation of List of Questionnaires for survey based user testing}

Survey Questionnaires are designed based on different website dimensions by considering various evaluation factors listed in Table 1.

Table 1. Questionnaires

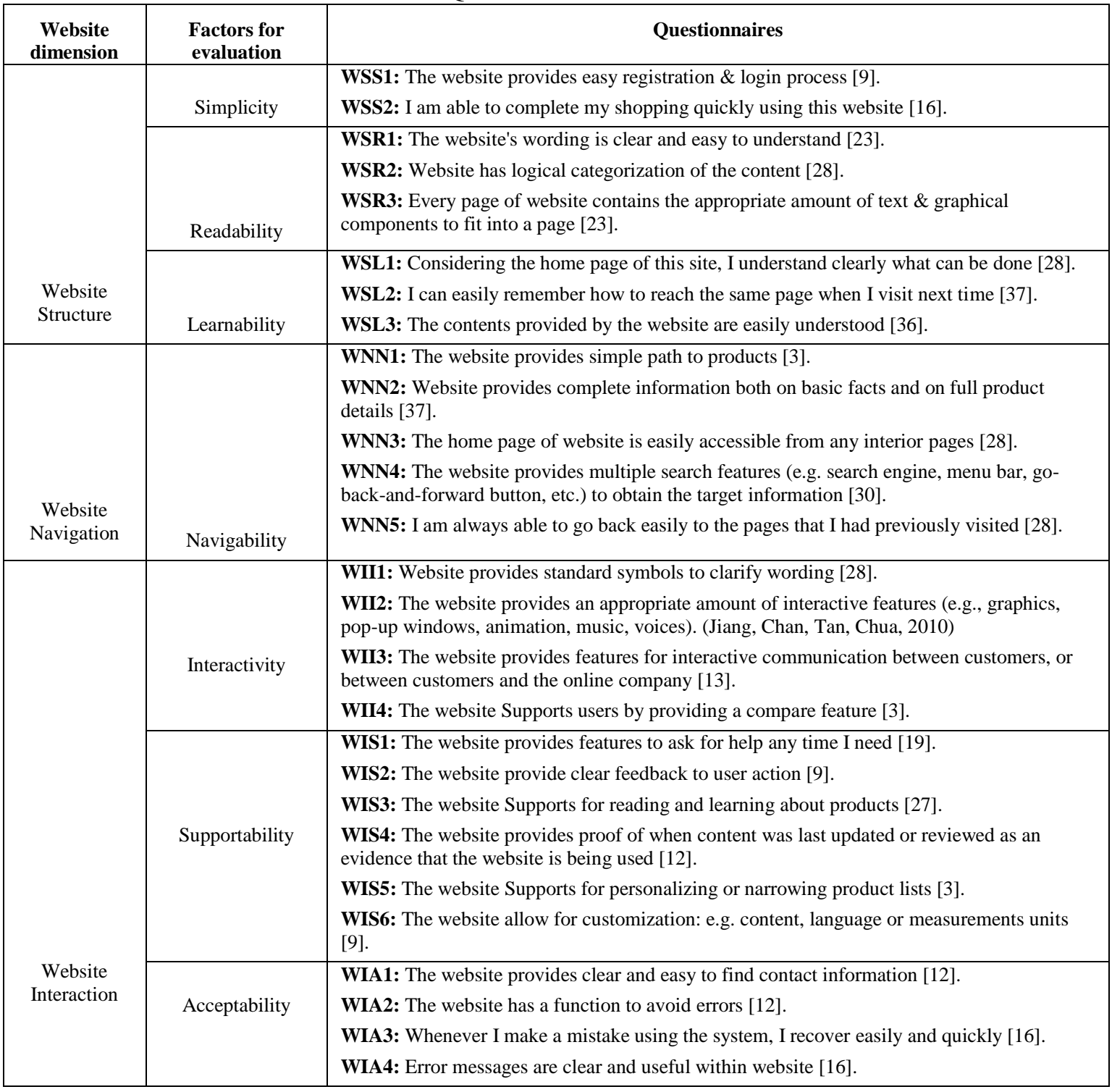

\subsection{Formation of List of task's for task based user testing}

Considering overall online shopping process it is divided into 10 subtasks.

- Open the website

- Check whether website has language localization option or not. 
- Get familiar with website and search for the product.

- $\quad$ Find required product by selecting price range, Comparing and finding similar products, viewing reviews and Comparison between sellers.

- $\quad$ Add and remove product to cart, change quantity, Place order.

- Registration and login process.

- Select payment option. Payment processing and view Confirmation of purchase.

- Track order, Cancellation or return process for placed order

- Get anytime help required.

- Go back to the product page \& write review on product if the product has already been used by users.

\section{III. documenting user mental model and Behavioral pattern}

318 participants were filled online survey. Based on frequency of computer and internet usage participants were divided into three categories beginners: Yearly computer and internet users, intermediates: weekly or monthly computer and internet users, Experts: Daily computer and internet users. Based on this 66 participants came under beginner category, 73 participants came under expert category and 179 participants came under intermediate category. Here we have considered 4 age ranges 18-25, 26-35, 36-45, $46 \&$ above. Education also has four ranges Below XII (Higher Secondary), XII (Higher Secondary), Graduate, Postgraduate $\&$ Above. Frequency of using shopping site we have weekly, yearly and monthly options. As currently among Indian E-commerce shopping site Flipkart, Amazon and Snapdeal have similar kind of GUI and they are top popular websites. So before preceding actual questionnaires users have selected one of the frequently used website. Analysis of user's demographic data is given in Table 2.

Table 2 Analysis of User's demographic characteristics

\begin{tabular}{|c|c|c|c|c|c|}
\hline Sr. No & Characteristics & Range & Beginners & Intermediates & Experts \\
\hline \multirow[t]{4}{*}{1.} & \multirow[t]{4}{*}{ Age } & $18-25$ & 11 & 88 & 37 \\
\hline & & $26-35$ & 23 & 44 & 22 \\
\hline & & $36-45$ & 24 & 38 & 10 \\
\hline & & $46 \&$ above & 8 & 9 & 4 \\
\hline \multirow[b]{4}{*}{2.} & \multirow[b]{4}{*}{ Education } & Below XII & 11 & -- & -- \\
\hline & & XII & 25 & 63 & 1 \\
\hline & & Graduate & 20 & 78 & 42 \\
\hline & & $\begin{array}{c}\text { Postgraduate } \& \\
\text { Above }\end{array}$ & 10 & 38 & 30 \\
\hline \multirow[b]{4}{*}{3.} & \multirow{4}{*}{$\begin{array}{c}\text { Frequency of } \\
\text { using Computer \& } \\
\text { Internet }\end{array}$} & Daily & -- & -- & 73 \\
\hline & & Weekly & -- & 148 & -- \\
\hline & & Monthly & -- & 31 & -- \\
\hline & & Yearly & 66 & -- & -- \\
\hline \multirow{3}{*}{4.} & \multirow{3}{*}{$\begin{array}{c}\text { Frequency of } \\
\text { using shopping } \\
\text { site }\end{array}$} & Weekly & -- & -- & 7 \\
\hline & & Monthly & -- & 52 & 45 \\
\hline & & Yearly & 66 & 127 & 21 \\
\hline \multirow[t]{3}{*}{5.} & \multirow{3}{*}{$\begin{array}{l}\text { Name of shopping } \\
\text { site using } \\
\text { frequently }\end{array}$} & Flipkart & 31 & 66 & 32 \\
\hline & & Amazon & 24 & 91 & 23 \\
\hline & & Snapdeal & 11 & 22 & 18 \\
\hline
\end{tabular}

It is observed from Table 2 that out of 318 participants very few are from age group $46 \&$ above. More participants are from age group 18-25. Frequency of participates with less education and aged are comparatively less. Also maximum participants who belongs to expert group have education Graduate and above. But many Graduate and above participants also Beginners and Intermediates. Means from age and education one cannot distinguish the participants in three categories. So we have considered frequency of using computer and internet as a demographic characteristic to distinguish participant into three categories.

\subsection{Evaluation of various website dimensions among various user groups}

Website dimensions are evaluated by beginners, intermediates and experts users through set of questionnaires given in Table 1 based on various evaluation factors. Graphs given below represents percentages calculated based on the responses of questionnaires submitted by participants. Responses where in Likert scale of 5 level. Level 1 Strongly Disagree, Level 2 Disagree, Level 3 Neutral, Level 4 Agree and Level 5 Strongly Agree. Now we have done comparative analysis for each evaluation factor among beginners, intermediates and experts. Same is represented from figure 1 to figure 7. 
100

5

$\begin{array}{llllll}\text { BWSS1 } & \text { BWSS2 } & \text { IWSS1 } & \text { IWSS2 } & \text { EWSS1 } & \text { EWSS2 }\end{array}$

Strongly Agree Agree Neutral Disagree Strongly Disagree

Fig. 1: Comparative Analysis for Simplicity among beginners, intermediates and experts

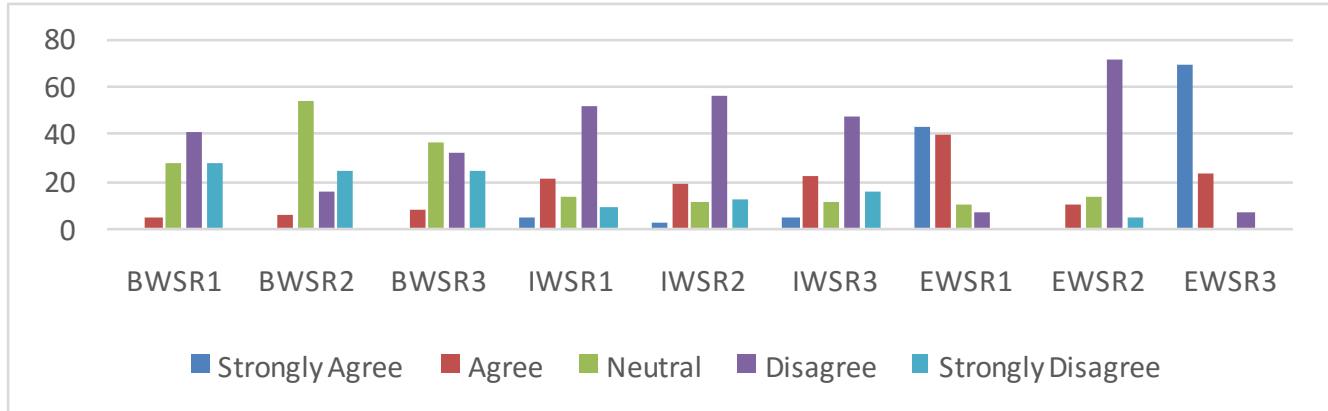

Fig. 2: Comparative Analysis for Readability among beginners, intermediates and experts

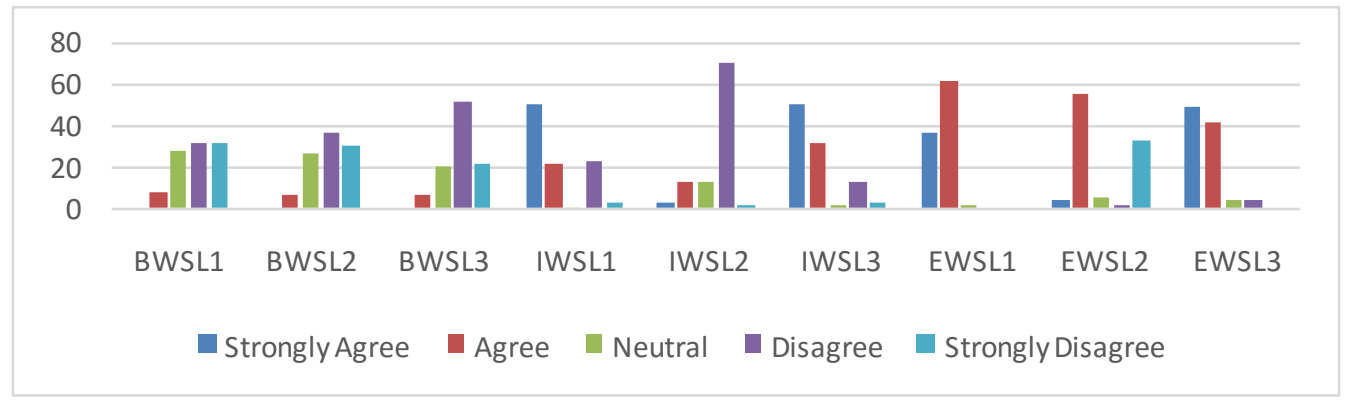

Fig. 3: Comparative Analysis for Learnability among beginners, intermediates and experts

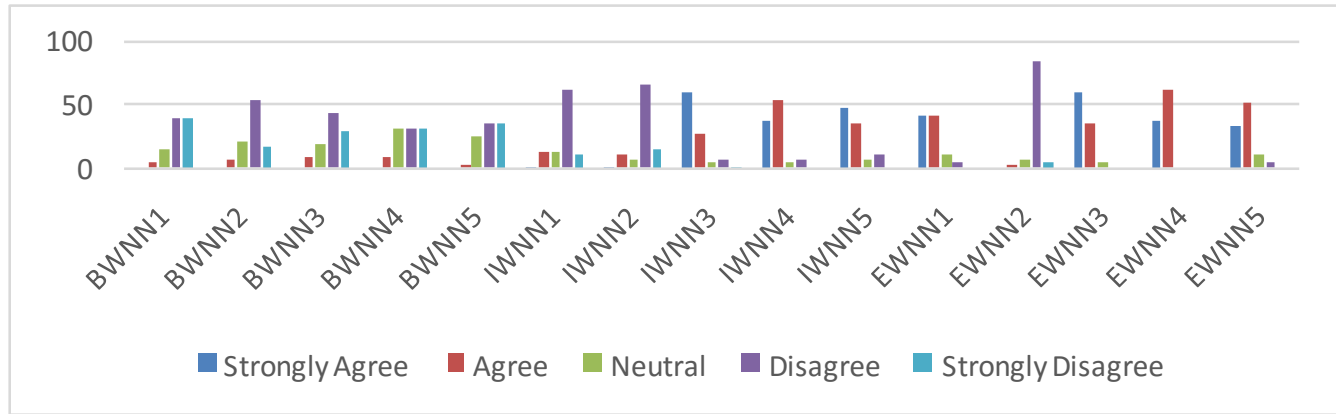

Fig. 4: Comparative Analysis for Navigability among beginners, intermediates and experts 


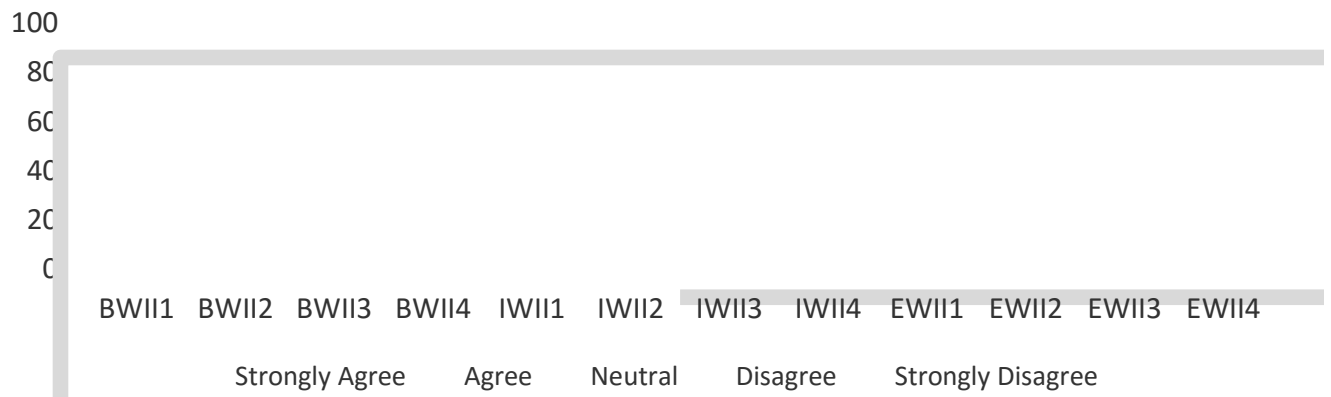

Fig. 5: Comparative Analysis for Interactivity among beginners, intermediates and experts

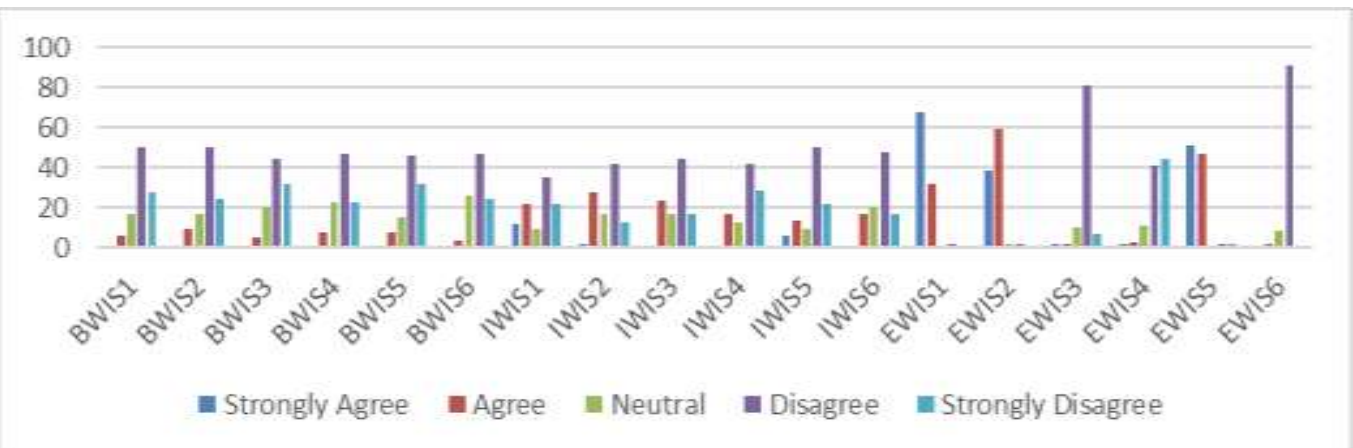

Fig. 6: Comparative Analysis for Supportability among beginners, intermediates and experts

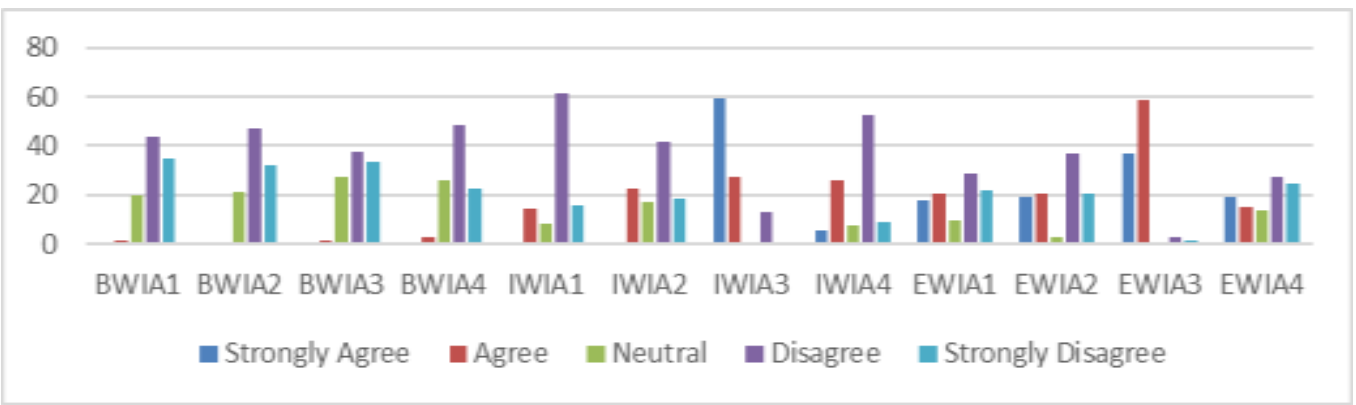

Fig. 7: Comparative Analysis for Acceptability among beginners, intermediates and experts

Expert users are satisfied with evaluation factors related to website dimension website structure and website navigation but they are unsatisfied for some evaluation factors of website interaction. Beginners are unsatisfied with almost all evaluation factors. Intermediates are satisfied with some evaluation factors in all website dimensions.

\subsection{Likert Score statistical analysis}

Likert score is also analyzed using other statistical measures Mean (M), Standard Deviation (S.D), Cronbach Alpha (C.A) and T-test. Average likert score mean for beginners is near to 2, intermediates is near to 3 and experts is near to 4. Means beginners have poor satisfaction. Intermediates have average satisfaction. Experts have better satisfaction than beginners and intermediates. Standard deviation for Beginners is 0.86, intermediates is 0.99 , experts is 0.83 and variance for beginners is 0.74 , intermediates is 0.99 , experts is 0.77 means on and average maximum likert score for beginners is near to 3 , intermediates is near to 4 and experts is near to 5.Cronbach alpha for beginners is 0.80 and for intermediates is 0.86 means responses from those user's group are less consistent as compare to experts which is 0.89 which is higher value for it means expert's samples are more consistent and reliable.

T-test is applied on Likert score of sample responses between different groups Beginners and Intermediates, Intermediates and experts and Beginners and experts. From Table 4. It is found that there is significant difference between these groups because value of $\mathrm{P}$ is $<0.05$. 
Table 3. Likert Score statistical analysis

\begin{tabular}{|c|c|c|c|c|c|c|c|c|c|c|c|c|}
\hline \multirow{2}{*}{$\begin{array}{c}\text { Evaluation } \\
\text { Factor }\end{array}$} & \multicolumn{4}{|c|}{ Beginners } & \multicolumn{4}{|c|}{ Intermediates } & \multicolumn{4}{|c|}{ Experts } \\
\hline & M. & S.D & Var. & C. $\mathbf{A}$ & M. & S.D & Var. & C.A & M. & S.D & Var. & C.A \\
\hline Simplicity & 2.21 & 0.86 & 0.74 & \multirow{8}{*}{0.80} & 3.43 & 0.81 & 0.65 & \multirow{8}{*}{0.86} & 4.45 & 0.54 & 0.29 & \multirow{8}{*}{0.89} \\
\hline Readability & 2.27 & 0.87 & 0.74 & & 2.51 & 1.06 & 1.12 & & 3.69 & 0.80 & 0.65 & \\
\hline Learnability & 2.12 & 0.90 & 0.81 & & 3.52 & 1.09 & 1.23 & & 3.90 & 0.7 & 0.5 & \\
\hline Navigability & 2.02 & 0.87 & 0.76 & & 3.47 & 0.88 & 0.77 & & 3.89 & 0.62 & 0.41 & \\
\hline Interactivity & 2.16 & 0.86 & 0.73 & & 2.4 & 0.94 & 0.93 & & 2.60 & 1.22 & 1.35 & \\
\hline Supportability & 2.06 & 0.86 & 0.73 & & 2.44 & 1.10 & 1.21 & & 3.24 & 0.61 & 0.4 & \\
\hline Acceptability & 1.96 & 0.78 & 0.61 & & 2.92 & 1.03 & 1.06 & & 3.17 & 1.30 & 1.77 & \\
\hline $\begin{array}{c}\text { Overall } \\
\text { Evaluation }\end{array}$ & 2.11 & 0.86 & 0.74 & & 2.96 & 0.99 & 0.99 & & 3.56 & 0.83 & 0.77 & \\
\hline
\end{tabular}

Table 4.T-test Results

\begin{tabular}{|c|c|c|c|c|c|c|}
\hline Between Group & Std Err & T-stat & df & P-value & t-crit & Sig \\
\hline Beginners and Intermediates & 0.027 & 29.77 & 4806.9 & 0.001 & 1.96 & Yes \\
\hline Intermediates and Experts & 0.0413 & 12.44 & 2391.6 & 0.001 & 1.96 & Yes \\
\hline Beginners and Experts & 0.056 & 22.13 & 1479.0 & 0.001 & 1.96 & Yes \\
\hline
\end{tabular}

\subsection{Mental model of end users}

From above Likert score percentage and statistics, mental model for beginners, intermediates and experts are formed and described in Table 5, Table 6 and Table 7 respectively.

Table 5. Mental model for Experts

\begin{tabular}{|c|c|c|}
\hline \hline $\begin{array}{c}\text { Website } \\
\text { Structure }\end{array}$ & $\begin{array}{c}\text { Website } \\
\text { Navigation }\end{array}$ & $\begin{array}{c}\text { Website } \\
\text { Interaction }\end{array}$ \\
\hline \hline Simplicity & & Interactivity \\
Strongly agree & & Neutral \\
\cline { 1 - 1 } Readability & Navigability & Supportability \\
Agree & Agree & Neutral \\
\cline { 1 - 1 } Learnability & & Acceptability \\
Agree & & Neutral \\
\hline
\end{tabular}

Table 6. Mental model for Intermediates

\begin{tabular}{|c|c|c|}
\hline \hline $\begin{array}{c}\text { Website } \\
\text { Structure }\end{array}$ & $\begin{array}{c}\text { Website } \\
\text { Navigation }\end{array}$ & $\begin{array}{c}\text { Website } \\
\text { Interaction }\end{array}$ \\
\hline \hline Simplicity & & Interactivity \\
Agree & \multirow{2}{*}{$\begin{array}{c}\text { Navigability } \\
\text { Neadability }\end{array}$} & Supporree \\
\cline { 1 - 1 } Neutral & Agree & Neutral \\
\cline { 1 - 1 } Aearnability & & Acceptability \\
& & Neutral \\
\hline
\end{tabular}


Table7. Mental model for Beginners

\begin{tabular}{|c|c|c|}
\hline \hline $\begin{array}{c}\text { Website } \\
\text { Structure }\end{array}$ & $\begin{array}{c}\text { Website } \\
\text { Navigation }\end{array}$ & $\begin{array}{c}\text { Website } \\
\text { Interaction }\end{array}$ \\
\hline \hline Simplicity & & Interactivity \\
Disagree & & Disagree \\
\cline { 1 - 1 } Readability & Navigability & Supportability \\
Disagree & Disagree & Disagree \\
\cline { 1 - 1 } Learnability & & Acceptability \\
Disagree & & Disagree \\
\hline
\end{tabular}

In Table 5. Mental model for experts is documented based on analysis of survey. All experts are completely satisfied with simplicity evaluation and satisfied for readability, learnability of website structure. Also they are satisfied with navigability of website navigation but they are not partially satisfied with interactivity, supportability and acceptability evaluation factor of website user interaction. In Table 6. Mental model of intermediates is documented based on analysis of survey. They are satisfied with simplicity and learnability evaluation factors of website structure but they are partially satisfied for readability evaluation factor of website structure. They are satisfied with navigability evaluation factor of website navigation but not satisfied for interactivity and partially satisfied for supportability and acceptability evaluation factor of website user interaction. In Table 7. Mental model of beginners is documented based on analysis of survey. They are not satisfied with simplicity, readability and learnability evaluation factors of website structure as well as navigability evaluation factor of website navigation and interactivity, supportability and acceptability evaluation factor of website user interaction.

Beginners are not satisfied with design of website because their current knowledge does not match with target knowledge required to understand the website. On other side experts are satisfied with design of website because their current knowledge is matching with target knowledge required to understand the website. But Intermediates are partially satisfied with design of website because their current knowledge is not exactly matching for target knowledge required to understand the website.

\subsection{Behavioral pattern of end users through task based user testing}

Ten tasks are designed based on different e-commerce processes for task based user testing and behavioral patterns are documented for beginners, intermediates and experts.

Table 8: Behavioral pattern of end users

\begin{tabular}{|c|c|c|c|c|}
\hline Task ID & Task & Beginners & Intermediates & Experts \\
\hline $\mathrm{T} 1$ & Open the website & $\begin{array}{l}\text { They searched website by } \\
\text { typing name of website in } \\
\text { Google search engine. }\end{array}$ & $\begin{array}{l}\text { They searched website by } \\
\text { typing name of website in } \\
\text { Google search engine but } \\
\text { few of them have typed } \\
\text { URL in browser. }\end{array}$ & $\begin{array}{l}\text { They Opened the website } \\
\text { by typing URL in } \\
\text { browser. }\end{array}$ \\
\hline $\mathrm{T} 2$ & $\begin{array}{l}\text { Check whether } \\
\text { website has language } \\
\text { localization option or } \\
\text { not. }\end{array}$ & $\begin{array}{l}\text { Few of beginners searched } \\
\text { language localization } \\
\text { option but it was missing } \\
\text { in website. }\end{array}$ & $\begin{array}{l}\text { No one searched for } \\
\text { language localization } \\
\text { because they were } \\
\text { comfortable with English. }\end{array}$ & $\begin{array}{l}\text { No one searched for } \\
\text { language localization } \\
\text { because they were } \\
\text { comfortable with English. }\end{array}$ \\
\hline T3 & $\begin{array}{l}\text { Get familiar with } \\
\text { website and search for } \\
\text { the product. }\end{array}$ & $\begin{array}{l}\text { They were confused to } \\
\text { read and understand the } \\
\text { website. They were not } \\
\text { comfortable for finding } \\
\text { relevant product page. } \\
\text { They required help. }\end{array}$ & $\begin{array}{l}\text { They were having partial } \\
\text { understanding of website } \\
\text { so they immediately } \\
\text { clicked on advertisement } \\
\text { and moved to that webpage } \\
\text { and become confused. } \\
\text { User preferred to find } \\
\text { product through search } \\
\text { engine. }\end{array}$ & $\begin{array}{l}\text { Users easily understand } \\
\text { how to use website. They } \\
\text { did not clicked on page } \\
\text { immediately but browse } \\
\text { the page up and down for } \\
\text { getting target information. } \\
\text { They managed to find the } \\
\text { relevant product through } \\
\text { menu bar comfortably. }\end{array}$ \\
\hline $\mathrm{T} 4$ & $\begin{array}{l}\text { Find required product } \\
\text { by Selecting price } \\
\text { range, Comparing and } \\
\text { finding similar } \\
\text { products, viewing } \\
\text { reviews and } \\
\text { Comparison between } \\
\text { sellers. }\end{array}$ & $\begin{array}{l}\text { They give up to find the } \\
\text { product based on one or } \\
\text { another factor price range, } \\
\text { Comparing and finding } \\
\text { similar products, viewing } \\
\text { reviews and Comparison } \\
\text { between sellers. }\end{array}$ & $\begin{array}{l}\text { They managed to find the } \\
\text { product only based on } \\
\text { price range and give up for } \\
\text { Comparing and finding } \\
\text { similar products, viewing } \\
\text { reviews and Comparison } \\
\text { between sellers. }\end{array}$ & $\begin{array}{l}\text { Users spend some time } \\
\text { for Selecting price range, } \\
\text { Comparing and finding } \\
\text { similar products, viewing } \\
\text { reviews and Comparison } \\
\text { between sellers but finally } \\
\text { found the required } \\
\text { product. }\end{array}$ \\
\hline
\end{tabular}




\begin{tabular}{|c|c|c|c|c|}
\hline T5 & $\begin{array}{l}\text { Add and remove } \\
\text { product to cart, change } \\
\text { quantity, Place order. }\end{array}$ & $\begin{array}{l}\text { They require some help to } \\
\text { perform all these subtask. } \\
\text { Some are showing lazy } \\
\text { ness to identify and enter } \\
\text { captcha during place order } \\
\text { process on some website. }\end{array}$ & $\begin{array}{l}\text { When user by mistake } \\
\text { removed product from cart } \\
\text { and want to add same } \\
\text { product again but there } \\
\text { was no option to go back } \\
\text { to the same product page } \\
\text { and redo the action so user } \\
\text { get confused. }\end{array}$ & $\begin{array}{l}\text { All users easily carried } \\
\text { out this task. }\end{array}$ \\
\hline T6 & $\begin{array}{l}\text { Registration and login } \\
\text { process. }\end{array}$ & $\begin{array}{l}\text { Finding difficulty in } \\
\text { forming password and } \\
\text { recall pin code. }\end{array}$ & $\begin{array}{l}\text { Some users forgot } \\
\text { password so they are } \\
\text { showing irritation to } \\
\text { recover it and proceed } \\
\text { further for purchase } \\
\text { process. }\end{array}$ & $\begin{array}{l}\text { All users easily performed } \\
\text { these subtasks. }\end{array}$ \\
\hline $\mathrm{T} 7$ & $\begin{array}{l}\text { Select payment option, } \\
\text { payment processing } \\
\text { and view Confirmation } \\
\text { of purchase. }\end{array}$ & $\begin{array}{l}\text { Confused to select } \\
\text { payment options and view } \\
\text { confirmation of purchase. }\end{array}$ & $\begin{array}{l}\text { Majority of them confused } \\
\text { where to look for } \\
\text { confirmation of purchase. }\end{array}$ & $\begin{array}{l}\text { All users easily performed } \\
\text { these subtasks. }\end{array}$ \\
\hline $\mathrm{T} 8$ & $\begin{array}{l}\text { Track order, } \\
\text { Cancellation or return } \\
\text { process for placed } \\
\text { order }\end{array}$ & $\begin{array}{l}\text { Difficulty to find } \\
\text { cancellation and return } \\
\text { process. }\end{array}$ & $\begin{array}{l}\text { Performed cancellation and } \\
\text { return by taking help from } \\
\text { site FAQs etc. }\end{array}$ & $\begin{array}{l}\text { All users easily performed } \\
\text { these subtasks. }\end{array}$ \\
\hline T9 & $\begin{array}{l}\text { Get anytime help } \\
\text { required. }\end{array}$ & $\begin{array}{l}\text { Unable to get anytime help } \\
\text { required. }\end{array}$ & $\begin{array}{l}\text { For some of queries they } \\
\text { got help but many queries } \\
\text { were unanswered. }\end{array}$ & $\begin{array}{l}\text { For majority of queries } \\
\text { they got help but for few } \\
\text { queries not able to get } \\
\text { help. }\end{array}$ \\
\hline T10 & $\begin{array}{l}\text { Go back to the product } \\
\text { page \& write review } \\
\text { on product if product } \\
\text { is already used by } \\
\text { users. }\end{array}$ & $\begin{array}{l}\text { Not shown interest as they } \\
\text { are beginners for website. }\end{array}$ & $\begin{array}{l}\text { Difficulty to remember and } \\
\text { go back to product page for } \\
\text { finding writes review } \\
\text { option. }\end{array}$ & $\begin{array}{l}\text { All users easily performed } \\
\text { these subtasks. }\end{array}$ \\
\hline
\end{tabular}

\section{Mapping of GUI with mental model and behavioral pattern of end user}

Mapping of GUI with mental model and behavioral pattern of end users is done and Gap identified in GUI of Existing E-commerce shopping site which is explained in table 9.

Table 9: Gap identified in GUI of Existing E-commerce shopping site

\begin{tabular}{|c|c|}
\hline Problem Theme & Gap identified in GUI of Existing E-commerce shopping site \\
\hline Language localization & $\begin{array}{l}\text { Language selection option is missing. If user is not familiar with English he/she cannot able to access } \\
\text { website effectively. }\end{array}$ \\
\hline Information overload & $\begin{array}{l}\text { For beginners and intermediates it is difficult for understanding home page because of information } \\
\text { overload. This is because of advertisements of special offers, Best deals of a day etc. }\end{array}$ \\
\hline Vertical Scrolling & $\begin{array}{l}\text { Too much vertical scrolling for home page and product catalogue pages. For beginners and } \\
\text { intermediates it is difficult to keep patience and attention while scrolling the page. }\end{array}$ \\
\hline $\begin{array}{l}\text { Number of attributes for } \\
\text { Refining catalogue }\end{array}$ & $\begin{array}{l}\text { There should be more number of attributes to refine product list so user will get personalized and } \\
\text { customized product list. }\end{array}$ \\
\hline Sub contents Listing & $\begin{array}{l}\text { Listing of sub contents should be done at the top of the page in case of longer web pages so that one } \\
\text { can view required sub contents. }\end{array}$ \\
\hline Compare feature & $\begin{array}{l}\text { Compare feature should be there for all products based on their basic attributes. In existing E- } \\
\text { commerce shopping site compare feature only exists for specific products. }\end{array}$ \\
\hline $\begin{array}{l}\text { Listing of similar } \\
\text { products and } \\
\text { recommended products }\end{array}$ & $\begin{array}{l}\text { On selected product page listing of similar products as well as recommended products based on } \\
\text { various criteria should be done. }\end{array}$ \\
\hline Cart Design & $\begin{array}{l}\text { "Remove" label should be in bold so beginners can remove product easily which is added by mistake } \\
\text { so there won't be any irritation. As well as for quantity there should be list box with limit based on } \\
\text { availability of products so user can select required number of items according to availability. }\end{array}$ \\
\hline $\begin{array}{l}\text { Login \& Registration } \\
\text { Process }\end{array}$ & $\begin{array}{l}\text { Users cannot remember password for each shopping site so for login process user would enter mobile } \\
\text { number and request for verification code. It will receive on mobile using that user will proceed for } \\
\text { login. During registration or during place order users are confused for pin code. On website there } \\
\text { should be provision to fetch pin code from address. }\end{array}$ \\
\hline Mode of Payment & $\begin{array}{l}\text { All modes should be listed properly in their full form with terms and conditions with attached notes } \\
\text { so users will avoid confusion. }\end{array}$ \\
\hline $\begin{array}{l}\text { Confirmation of } \\
\text { purchase }\end{array}$ & There is need to modify layout of confirmation of purchase for beginners understanding. \\
\hline $\begin{array}{l}\text { Options for Track order, } \\
\text { Cancellation or return } \\
\text { process for placed order }\end{array}$ & $\begin{array}{l}\text { Links to all this subtasks should be at top of the home page. In some existing web sites on } \\
\text { confirmation of purchase page "my orders" link is given which is further linked to home page by } \\
\text { label "track order". For beginners it may lead to confusion. }\end{array}$ \\
\hline Help & $\begin{array}{l}\text { There is need to provide customer care toll free number at the top of home page as well as there } \\
\text { should be option of live chat for interaction of customers with company, sellers or other customers. }\end{array}$ \\
\hline
\end{tabular}


Investigating Procedures for Intuitive GUI design of Indian E-Commerce shopping sites

\begin{tabular}{|l|l|}
\hline & Complete seller details with contact information is required on product page. \\
\hline $\begin{array}{l}\text { Write a review for } \\
\text { products }\end{array}$ & $\begin{array}{l}\text { On product page for write review link there should be linked note to explain importance and benefits } \\
\text { of write review so customers will show interests. }\end{array}$ \\
\hline Website Wording & $\begin{array}{l}\text { All words should be meaningful and supported by standard symbols (metaphors) so beginners can } \\
\text { easily understand. }\end{array}$ \\
\hline $\begin{array}{l}\text { 'Logical categorization } \\
\text { of contents }\end{array}$ & $\begin{array}{l}\text { In some cases logical categorization of contents are missing. Categorization is always done based on } \\
\text { product features. Need based categorization is missing. }\end{array}$ \\
\hline Navigation & $\begin{array}{l}\text { In some cases Link name did not match with the contents of destination page. As well as links are not } \\
\text { situated in an obvious location on a page so users could not recognize it. A page did not have } \\
\text { navigation link to other required pages in a site. }\end{array}$ \\
\hline $\begin{array}{l}\text { Product description and } \\
\text { learning about the } \\
\text { product }\end{array}$ & $\begin{array}{l}\text { There should be complete description for the product. Real product positioning and how to use } \\
\text { product should be properly represented. }\end{array}$ \\
\hline $\begin{array}{l}\text { Feedback \& error } \\
\text { messages to user action }\end{array}$ & $\begin{array}{l}\text { Feedback and error message to user action should be properly highlighted so it can be properly } \\
\text { distinguished to user. }\end{array}$ \\
\hline Function to avoid error & At all clicks and text boxes, click or data entry validation should require avoiding errors. \\
\hline $\begin{array}{l}\text { Date of last } \\
\text { modification }\end{array}$ & $\begin{array}{l}\text { There should be date of last modification so users can keep track of when there is change in price or } \\
\text { any discount or offer. }\end{array}$ \\
\hline
\end{tabular}

\section{Procedures or design guidelines to make intuitive GUI of E-commerce Shopping Site}

Procedures are mainly related to website structure, website navigation, website interaction related to seven evaluation factor.

- Simplicity: Keep registration, login and whole purchase process including finding product, make payment, order confirmation, cancellation of order, and return of product etc. easy to understand in all aspects to end users in website.

- Readability: Website wording, logical categorization of contents, appropriate amount of text and graphical components to fit into a page would make easy to understand the website to end users.

- Learnability: Contents provided by the website should be easily understood to users. Design a home page in such a way that users can easily understand what can be done further. Overall design should be more memorable even if user uses website after long time. So automatically the capability of a website to enable the user to learn how to use it will get maximized.

- Navigability: Website should provide simple path to products as well as complete information of basic facts and full product details though multiple search features. The home page of website should be easily accessible from any interior pages. Users should be able to go back easily to the pages that they had previously visited. Means website facilitates easy movement from one web page to another web page.

- Interactivity: Website should provide standard symbols to clarify wording, interactive features e. g graphics, popup windows, animation, music, voices, features for interactive communication between customers, or between customers and the online company and compare features for appropriate interaction between user and website.

- Supportability: The website should provide help which any time user need, clear feedback to user action, proof of when content was last updated as well as It should supports for reading and learning about products, personalizing or narrowing product list, allow for customization: e.g. content, language or measurements units etc. to support user in their shopping process.

- Acceptability: The website should provide a function to avoid errors, a method to recover from mistake easily \& quickly, clear and useful error messages and clear and easy to find contact information to get acceptability from users.

\section{Conclusion}

The study has illustrated how the proposed approach using survey and task based user testing helped to distinguish end users in three category beginners, intermediates and experts based on computer literacy. Responses are collected using survey and analyzed percentage wise as well as using statistical measures for various evaluation factors of website dimensions. Analyzed results are documented in form of mental models. Three different mental models are constructed for beginners, intermediates and experts. As well as tasks are designed to document behavioral pattern of different users groups beginners, intermediates and experts. Mental model and behavioral patterns are further mapped with existing e-commerce shopping websites and problem themes are identified and gap identified are elaborated further. Finally we have concluded work by listing design guidelines or procedures to make GUI intuitive. This work will definitely help us to design prototype GUI for intuitive ecommerce shopping site so less computer literate user can use e-commerce shopping site easily. 


\section{Acknowledgements}

My special thanks to the research head Dr. G.T Thampi and my guide Dr. Madhuri Rao who have contributed towards development of the paper and encouraging me to write this paper.

\section{References}

[1]. Alghamdi, A., Aldabbas, H., Alshehri M.,and Nusir M.(2012). Adopting User-Centred Development for Arabic E-Commerce Websites. International Journal of Web \& Semantic Technology (IJWesT) Vol.3, No.2.

[2]. Ahmed, M., Kaysar, J., and Rahman, N. (2011). Design Approaches to Enhance Usability for E-Commerce Sites. IJCSI International Journal of Computer Science Issues, Vol. 8, Issue 6, No 1, ISSN (Online): 1694-0814.

[3]. Benbunan-Fich, R., (2001). Using protocol analysis to evaluate the usability of a commercial web site. Information \& Management, 39(2), pp.151-163.

[4]. Bruijn, O., Angeli, A., Sutcliffe, A., (2007). Customer experience requirements for E-commerce websites. Int. J. Web Engineering and Technology, Vol. 3, No.4.

[5]. Chen, L., Gillenson, M. L., \& Sherrell, D. L. (2004). Consumer acceptance of virtual stores: A theoretical model and critical success factors for virtual stores. ACM SIGMIS Database, 35(2), 8-31.

[6]. Christopher, D., Lee, J., Liu, Y., and Sallie E., Becker, G., (2004). An Introduction to Human Factors Engineering. Second Ed. Upper Saddle River. NJ: Pearson Prentice Hall, 185-193.

[7]. Darejeh, A., and Singh, D., (2013). A Review on User Interface Design Principles to Increase Software Usability for Users with Less Computer Literacy. Journal of Computer Science 9 (11): 1443-1450, ISSN: 1549-3636

[8]. Eda, C., Afrancisco, J., Oz-Leiva, M., Luque, T., (2007). Web Acceptance Model (WAM): Moderating Effects of User Experience. Information \& Management (44): 384-396.

[9]. Egger, F.N., (2001). Affective design of e-commerce user interfaces: How to maximise perceived trustworthiness. In: Proc. Intl. Conf. Affective Human Factors Design, Singapore, London: Asean Academic Press.

[10]. Eksioglu, M., Varol, S., Duman, Y. (2015). An Investigation of User-Experience Design of E-Commerce Websites. Proceedings of the World Congress on Electrical Engineering and Computer Systems and Science, Barcelona, Spain.

[11]. HASAN, L., MORRIS, A., and PROBETS, S., (2013). E-commerce websites for developing countries _ a usability evaluation framework. Emerald Group Publishing Limited, Online Information Review, 37 (2), pp. 231 - 251.

[12]. Huang, Z. and Benyoucef, M., (2014). Usability and credibility of e-government websites, Government Information Quarterly, 31(4), pp.584-595.

[13]. Jiang, Z., Chan, J., Tan, B.C. and Chua, W.S., (2010). Effects of interactivity on website involvement and purchase intention. Journal of the Association for Information Systems, 11(1), pp.34-59.

[14]. Kendall \& Kendall, (2014). Human Computer Interaction. Pearson Education.

[15]. Koufaris, M., (2000). System design and consumer behavior in electronic commerce. Dissertation Abstracts International, 61(9), 3661. (UMI No. 9988944)

[16]. Lewis, J.R., (1995). IBM computer usability satisfaction questionnaires: psychometric evaluation and instructions for use International Journal of Human Computer Interaction, 7(1), pp.57-78.

[17]. Lisbeth, T., (2007). The Role of Aesthetics in Web Design. Nordicom Review (28): 63-76

[18]. Loeffler, D., Hess, A., Maier, A., Hurtienne, J., Schmitt, H., (2014). Developing Intuitive User Interfaces by Integrating Users' Mental Models into Requirements Engineering. The British Informatics Society Ltd.

[19]. Lohse, G.L. and Spiller, P., (1999). Internet retail store design: How the user interface influences traffic and sales. Journal of Computer Mediated Communication, 5(2), pp.1-2.

[20]. Mandel, T., (1997). The Elements of User Interface Design. John Wiley \& Sons.

[21]. Matz, K., (2012, June). Donald-Normans-design-principles-for-usability. Retrieved July 2016 from http://architectingusability.com

[22]. Nielsen, J., (1995, January). 10 Usability Heuristics for User Interface Design. Retrieved July 2016 from https://www.nngroup.com/articles/ten-usability-heuristics/

[23]. Nielsen, J., (1999). Designing web usability: The practice of simplicity. San Francisco: New Riders Publishing

[24]. O'Donnell, J. B. (2002). Assessment of the impact of Web site design on consumer trust and the purchase decision. Dissertation Abstracts International, 63(8), 2936. (UMI No. 3063155)

[25]. Panda, S., (2014). A Usability Evaluation Framework for B2C E-Commerce Websites, Computer Engineering and Intelligent Systems, Vol.5, No.3, ISSN 2222-2863 (Online).

[26]. Panda, s., Swain, s., Mall, R. (2015). An Investigation into Usability Aspects of E-Commerce Websites Using Users' Preferences. ACSIJ Advances in Computer Science: an International Journal, Vol. 4, Issue 1, No.13, January ISSN: 2322-5157

[27]. Rinder, J.M., (2012). The Importance of Website Usability Testing. MSc. University of Oregon.

[28]. Roy, M., Dewit, O. and Aubert, B.A., (2001). The impact of interface usability on trust in web retailers. Internet Research, 11(5), pp.388-398.

[29]. Saini, R., (2013, September). Graphical User Interface Design Essentials \& Process. International Journal of Advanced Research in Computer Science and Software Engineering, Volume 3, Issue 9.

[30]. Shneiderman, B., (1986). Designing the user interface-strategies for effective human-computer interaction, New Delhi: Pearson Education India.

[31]. Smith,T., (2008). Senior Citizens and E-commerce Websites: The Role of Perceived Usefulness, Perceived Ease of Use, and Web Site Usability. Informing Science: the International Journal of an Emerging Transdiscipline, Volume 11.

[32]. Stone, John, (2009). 20 Do's and Don'ts of Effective Web Typography. Retrieved on July 2016 http://www.webdesignledger.com/

[33]. Storto, C., (2009). A Distributed Cognition Framework to Compare E-Commerce Websites Using Data Envelopment Analysis. World Academy of Science, Engineering and Technology.

[34]. Tidwell, J., (1999, May). The Case for HCI Design Patterns. Retrieved from Http://Www.Mit.Edu/ / Patterns Essay.Html

[35]. Puzis, Y., Borodin, F. Ahmed, I.V. Ramakrishnan, (2012). An Intuitive Accessible Web Automation User Interface, 21st International World Wide Web Conference

[36]. Zhang, P., Small, R.V., Von Dran, G.M. and Barcellos, S., (2000). A two factor theory for website design. In: Proceedings of the 33rd Annual Hawaii International Conference on System Sciences. Maui, Hawaii, New Jersey: IEEE.

[37]. Zviran, M., Glezer, C. and Avni, I., (2006). User satisfaction from commercial web sites: The effect of design and use. Information \& Management, 43(2), pp.157-178 